by Philipp Schmidt-Thomé ${ }^{1}$, Johannes Klein ${ }^{1}$ and Jonas Satkunas ${ }^{2}$

\title{
Climate change, impacts and adaptation - some examples of geoscience applications for better environmental management in the Baltic Sea Region
}

\author{
IUGS-GEM Working Group on Climate Change Adaptation \\ ${ }^{1}$ Geological Survey of Finland. E-mail: philipp.schmidt-thome@gtk.fi; johannes.klein@gtk.fi \\ ${ }^{2}$ Lithuanian Geological Survey. E-mail: jonas.satkunas@lgt.lt
}

Geoscientists play an increasingly important role in understanding climate change and its impacts. This is especially the case with adaptation to climate change which cannot be solved in isolated attempts, but calls for international cooperation and integrated approaches. The potential effects of climate change on natural hazards, as well as water and energy resources, are of great concern to geoscientists and stakeholders. Climate change has only recently been incorporated into decision-making processes and spatial planning. In order to facilitate communication of potential impacts of climate change, and to determine strategies and measures to adapt to those, in October 2009 the IUGS Commission on Geoscience for Environmental Management (GEM) established a Working Group on Climate Change Adaptation (http://climate.iugsgem.org/).

This article presents some results of projects on climate change adaptation in the Baltic Sea Region (conducted by multi-disciplinary project teams under the lead of the Geological Survey of Finland). This paper was elaborated under the auspices of the BaltCICA project and IUGS-GEM.

\section{Introduction}

In the first decade of the $21^{\text {st }}$ century climate change and its potential impacts on human society has developed from a scientific discussion towards a nearly omnipresent issue in sciences, daily media, and political agendas. It is not questionable that the Earth's climate has been warming over the last 100 years and has led to a measurable shift in climate zones in Europe (Gerstengarbe and Werner, 2009). A very important discussion is the potential impact of climate change on the frequency and magnitude of natural hazards. There are observations of an increase in the magnitude for tropical storms in some regions. An increase in frequencies is not traceable; in fact there might be a decrease in storm frequency (Knutson et al., 2010; Storch and Weise, 2008). Nevertheless hydro-meteorological hazards will remain a highly potential source of adverse impacts on human settlements, especially as they also trigger important hazards such as storm surges and floods. Human vulnerability to extreme events has been rising, even despite climate change impacts (Topics Geo..., 2009). While there has been a strong increase in damages and costs, especially over the last 30 years, a normalization of the costs shows no trends of a rise in either frequency or magnitude (Pielke Jr. et al., 2008). With a continually expanding population, and a strong trend to settle in coastal and flood prone areas (Planning..., 2009), one question will certainly remain of high importance: How can land-use planning properly respond to the potential impacts of natural hazards, and the potential impact of climate change on those? In other words, how can spatial planning respond to extreme events, and what kind of knowledge is required to support decision makers?

This article describes approaches developed by an integration of several scientific disciplines including geosciences to support planners and decision-makers in finding appropriate, and cost-beneficial, approaches to adapt to current extreme events and also taking into account potential future changes.

The Geological Survey of Finland (GTK) is the lead partner of the "Climate Change: Impacts, Costs and Adaptation in the Baltic Sea Region" (BaltCICA) project. The project is part-financed by the European Union (EU) Baltic Sea Region Programme 2007-2013 and comprises 24 partners including municipalities, regional authorities and research institutes (Fig. 1). The project duration is from February 2009 to January 2012. The BaltCICA project builds on the experiences gained from the INTERREG IIIB projects "Sea level change affecting the spatial development in the Baltic Sea Region" (SEAREG) and "Developing Policies \& Adaptation Strategies to Climate Change in the Baltic Sea Region" (ASTRA), of which GTK was also the lead partner. All three projects follow a logical chain of development. While SEAREG laid the basis of rising awareness of potential climate change impacts on regional development (Schmidt-Thomé, 2006), ASTRA went a step further and assessed potential impacts (Hilpert et al., 2007). 


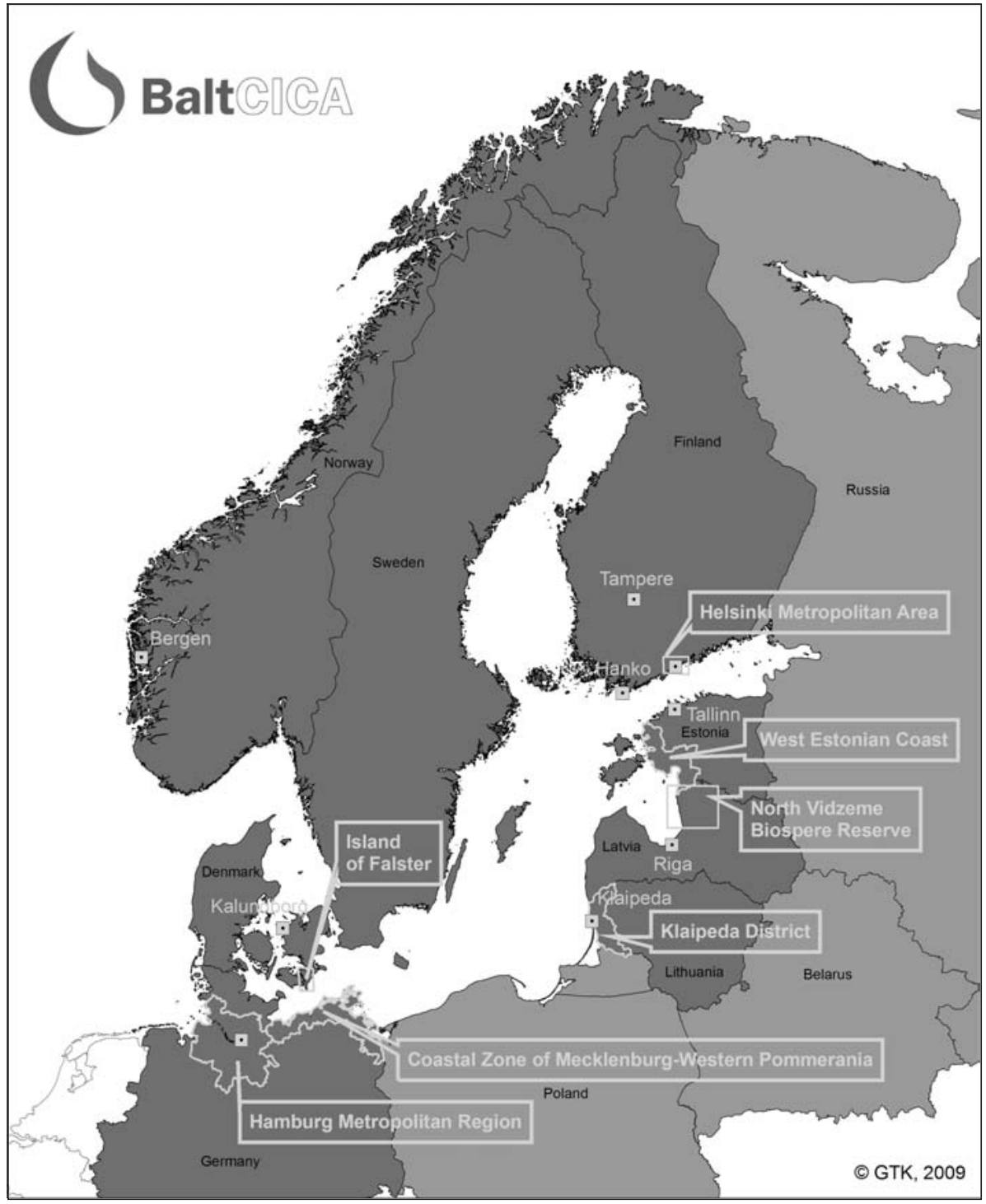

Figure 1. Case Studies areas of the BaltCICA project (www.baltCICA.org).

future climates. Often past climate changes that can be deduced from geological records may help in understanding the speed of potential climate change effects, i.e. how quickly have sea levels changed, how drastic has nature reacted to ups and downs in temperature, etc. These analyses of past events help in giving outlooks on potential changes in our living environment. It is also of important to understand the magnitude and potential effects of extreme events, such as droughts and floods.

\section{Groundwater - the key geoenvironmental issue in Europe}

At present, surface water plays a substantial role in public water supply in European countries (Table 1) and an increase in the share of groundwater to the public water supply is observed (Zektser, 2004). This is because groundwater has advantages over surface water. Groundwater generally contains micro and macro components needed for the human body; it does not require expensive treatment, and is much better protected from contamination (Zektser, 2004). The EU has a number of directives and regulations that aim to protect water resources (Water protection..., 2008). These include the Urban Waste Water, Nitrates, and Drinking Water Directives, and a Directive on Integrated Pollution Prevention and Control that requires licensing of discharges at sustainable levels. A coherent water policy was developed by 1995 but the measures focused on preventing emissions

The BaltCICA project supports local and regional decision-makers in evaluating and implementing adaptation measures.

\section{Why it is Important that Geology Participates in Climate Change Impact Research}

Climate change belongs to one of the most recent emerging scientific endeavors of which society demands reliable scientific answers. Geoscientists have been researching the causes and extents of climatic changes in Earth history for a long time. Most of the current climate change research is largely based on numerical modeling and focuses on future developments and impacts, and how climate change could be mitigated. The equally important research field of adapting to climate changes is now evolving strongly, especially in political contexts (Adapting..., 2009). Because of its deep understanding of climate changes in Earth history, geology can deliver important contributions to the questions arising around the capacities and necessities of our society to adapt to both the current and potential leading to more pollution, rather than the improvement of water resources. The EU Water Framework Directive (2000/60/EC) establishing a framework for Community action in the field of water policy was adopted in 2000. This Directive requires the establishment of technical specifications to complement the overall water (surface water, groundwater, and coastal beaches) regulatory regime. These specifications cover a number of key elements that range from the characterization and analyses of pressures and impacts, towards monitoring of measures. All of these elements are linked to the development and implementation of river basin management plans aimed at achieving "good environmental status" by 2015 .

Taking into consideration that groundwater is very important and in some countries is the only source of potable water (in general in Europe $65 \%$ of potable water is taken from groundwater aquifers) in 2006 the European Commission adopted a new directive - the Groundwater Directive (2006/118/EC), which is aimed at protecting groundwater from pollution. Based on an EU-wide approach the Directive introduced for the first time the quality objectives which oblige Member States to monitor and assess groundwater quality on the basis of common criteria, and identify and reverse trends in groundwater pollution. 
Table 1. Groundwater percentage for potable water supply in European cities (Zektser, 2000)

\begin{tabular}{lccc}
\hline City & $\begin{array}{r}\text { Population } \\
\text { mln. }\end{array}$ & $\begin{array}{c}\text { Surface water } \\
\%\end{array}$ & $\begin{array}{c}\text { Groundwater } \\
\%\end{array}$ \\
\hline Amsterdam & 1.3 & 52 & 48 \\
Barcelona & 3.3 & 83 & 17 \\
Berlin & 5.6 & 58 & 42 \\
Brussels & 2.3 & 35 & 65 \\
Vienna & 1.7 & 5 & 95 \\
Hamburg & 3.6 & & 100 \\
Glasgow & 5.2 & 63 & 37 \\
Copenhagen & 1.0 & 16 & 84 \\
Lisbon & 2.1 & 45 & 55 \\
London & 6.7 & 86 & 14 \\
Madrid & 4.1 & 91 & 9 \\
Moscow & 8.5 & 98 & 2 \\
Munich & 1.6 & & 100 \\
Paris & 7.1 & 60 & 40 \\
Rotterdam & 1.4 & 90 & 10 \\
Zurrich & 0.5 & 70 & 30 \\
\hline
\end{tabular}

The use of groundwater for public water supply is increasing in Europe, and especially in bigger cities. However, it is estimated that $60 \%$ of European cities overexploit their groundwater resources (Water protection..., 2008) European countries which use a high percentage of groundwater for public water supply can be listed in the following order: Lithuania $-100 \%$, Denmark $-98 \%$, Italy $-93 \%$, Hungary $-90 \%$, Poland $-70 \%$, Estonia $-65 \%$, Romania - 43\%, UK - 35\%, Scandinavian countries, Ireland - 15\%. This raises an important question of how climate change can potentially effect recharge, availability, and quality, of groundwater resources. The ASTRA and BaltCICA projects have several case studies that address wide ranges of potential impacts, some of which are described in more detail below.

Water issues in the European Union

http://europa.eu/scadplus/leg/en/s15005.htm

- $20 \%$ of surface water within the European Union is seriously threatened by pollution,

- $60 \%$ of European cities overexploit their groundwater resources,

- since 1985 , the area of irrigated land has increased by $20 \%$ in Southern Europe,

- the number of regions and populations affected by drought has increased by approximately $20 \%$ between 1976 and 2006,

- in 2003, one of the longest droughts affected more than 100 million people and one third of the territory of the European Union,

- droughts in the last thirty years have cost a total of 100 billion Euro.

\section{Examples from the Baltic Sea Region}

The concentration of large parts of its population and many larger cities in the coastal areas make the Baltic Sea Region sensitive to climate changes. Among others, sea level rise and impacts on drinking water availability and quality (both surface and ground water) can be expected to have important socio-economic impacts. Already under present climatic conditions, many coastlines in the Southern Baltic Sea face coastal retreat. The public water supply of many coastal municipalities is currently depending on shallow groundwater aquifers vulnerable and sensitive to changes in precipitation patterns and sea level. The intrusion of brackish water can affect water quality of water supply facilities and requires measures such as relocation of the well, or adjustment of the water pumping rate (Tarvainen et al., 2010).

Changes in the hydrological cycle and higher temperatures (of water and air) can lead to shifts in the yearly groundwater cycle and runoff patterns in rivers and catchment areas (Graham, 2004; Meier et al., 2006). Most climate change scenarios expect higher temperatures and higher precipitation in the yearly average, especially in wintertime, which leads to changing snow cover and flood patterns. In the Baltic Sea Region possibly higher evapotranspiration, and a shift of the runoff peaks to an earlier time in the year (caused by less snow and more rain in winter), can contribute to droughts in summertime (Ruosteenoja et al., 2005).

The aim of applied interdisciplinary climate change impact research is to achieve a better capability to deal with the impacts at those levels, where reliable adaptation measures have to be implemented, and are visible and tangible for the population. Assessment of climate change impacts on water bodies contributes to the development of methods for safeguarding sustainable water supply in both quality and quantity. Special emphasis is on adaptation to sea level rise, and changing flood patterns, for settlements located on the Baltic coast.

\section{Kokkola}

Kokkola, a medium sized town on the west coast of Finland, was one case study of the ASTRA project. Kokkola was founded in 1620 adjacent to the Bothnian Bay (Baltic Sea). In this area the land uplift due to postglacial rebound normally amounts to 7 to $8 \mathrm{~mm}$ per year (JHS 163..., 2008; Vestøl, 2006), and due to the retreating sea the original city centre nowadays lies about $2.0 \mathrm{~km}$ distant from the shoreline. Rising sea levels have made the glacial rebound less effective over the recent years so that the net land rise has slowed to about 4-5 mm per year relative to the mean sea level (Granberg, 2000). Normal sea level variation in Kokkola is between $-1.0 \mathrm{~m}$ to $+1.5 \mathrm{~m}$ relative to mean sea level. The city planning office of Kokkola was thus interested in sea level rise scenarios for the $21^{\text {st }}$ century. The background is that Kokkola experiences a strong pressure on coastal housing development. If the coastal land uplift continued at the present rate the coastal areas could be easily developed for housing, even with the lower glacial rebound effect of $5 \mathrm{~mm}$ per year. But what if the sea level rise and storm flood events would become stronger and flood patterns changed?

Kokkola participated in the ASTRA project to better understand the climate change scenarios and to evaluate how these can be integrated into local planning. The uncertainties of climate change scenarios played an especially important role in the assessments. Finally the city chose to use the "high case" sea level change scenario originally developed under the SEAREG project, which uses regional model results from the RCAO model driven by the ECHAM4/OPYC3 under the A2 emission scenario together with a global average sea level rise of $88 \mathrm{~cm}$ (Meier et al., 2006). According to these scenarios it would be possible that the land uplift would be neutralized by sea level rise, in other words the present coastline would not change over the $21^{\text {st }}$ century. Consequently, the often predicted increasing wind speed peaks during storm events, and the increase in heavy rainfalls, would lead to flood prone area changes. Two important locations for future housing development in Kokkola are the area of the 2011 housing fair and the Bride Island. 


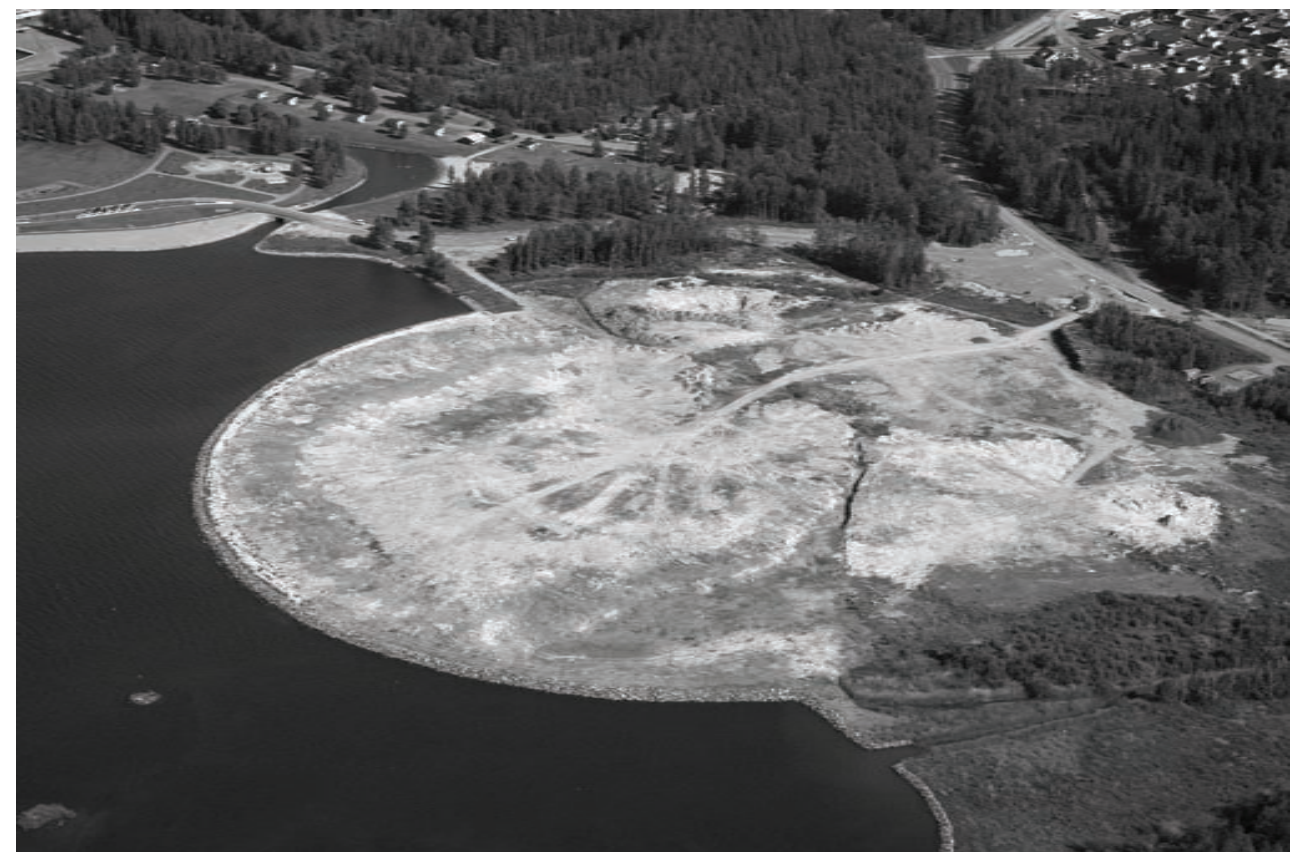

Figure 2. Housing fair ground in Kokkola. Artificial landfill to raise building ground higher above sea level. Picture: City of Kokkola

The area for the housing fair to be held in 2011 was planned several years ago. Such a housing fair is an important event in Finland, as the display houses built for the fair are later to be used for housing, which is an important asset for the investors. The housing fair in Kokkola is planned in a new housing area on the sea shore. In the course of the ASTRA project the location of the housing fair 2011 was not changed, but the minimum elevation of the building ground above mean sea level had risen by $1.0-1.2 \mathrm{~m}$ compared to previous seashore plans and is about $3.5 \mathrm{~m}$ (streets $3.0 \mathrm{~m}$ ) above the mean sea level. In other words, the decision was taken that sea shore plots may be built up, but it has to be made sure that the lowest floor of the houses is well above potential flood levels. The cost of each plot and house was calculated, including the artificial rise of the building ground, and the investors were willing to take this extra cost because the demand for houses located on the sea shore is still rising.

The second example, the Bride Island is a very popular place for summer cottages in the close vicinity of the city. The current trend in many European countries is to improve these temporary summer homes into houses that can be used all year round, and even to convert them into permanent homes. If the land continued to rise out of the sea as it has done so far, such a conversion from a temporary to a permanent home would pose no problem. The interest of the land owners is certainly not only in converting the houses; the investments would also be justified by the increasing land and house prices. The city of Kokkola on the other hand carries responsibilities if land-use plans are changed and natural hazards start to threaten housing areas. Due to the scenarios used in the ASTRA project land-use plan changes for the Bride Island were put on hold until improved climate change scenarios and observed trends are analyzed. However, sea level change scenarios are taken into account in the minimum elevation of buildings above mean sea level, e.g. when old cottages are renovated. Lowest building elevation for the newest building permits has been increased to $2.5 \mathrm{~m}$ above the mean sea level - so, in renovating buildings the adaptation to sea level rise is put into practice in small steps, or plot by plot.
Recommendations of the ASTRA project were also taken into account in building and city planning regulations. Several regulations have been developed to protect from rising wind speeds, cold winds, and storms on the shore. For example, low houses with optimal roof pitch against wind turbulence on yards; inner courtyards towards the south; plantations and fencing against cold wind directions; and also directing main streets crosswise to predominant coldest winds directions to avoid wind tunnel effects.

\section{Hanko}

The Hanko case study of the BaltCICA project focuses on researching impacts of climate change on a shallow groundwater formation located in the sea shore environment of the Baltic Sea in Southern Finland. The Hanko Cape consists of relatively low sand and gravel deposits the altitude is on average only 13 meters above sea level. It is part of the first Salppausselkä end moraine formation, the largest groundwater reservoir and gravel resource in Finland. The water supply for 10,000 inhabitants, industry, and harbor areas in Hanko is based completely on the fresh water of this formation.

Today the impact of sea level fluctuations on the groundwater already exists, causing problems concerning both water quantity and quality in the wells of the water works. (Tarvainen et al., 2010). All the underground infrastructure of the town is especially sensitive to changes in groundwater level.

The goal of the Hanko case study is to create a structural model of the groundwater body and to model the groundwater flow. Climate change scenarios are being applied to assess future options for the management of water resources. The aim is to develop a backup-plan safeguarding water supply under changing climate conditions.

All relevant data for the modeling are compiled. Data have been sought and collected from all the organizations operating in the study area: Geological Survey of Finland, Hanko city, Uusimaa Regional Environment Centre, Finnish Road Administration, Port of Hanko, VR - Finnish Rail Transport Company, Finnish Defence Forces, and local industries. Field studies including geophysical methods were conducted, and groundwater observation wells were installed, in areas where no data are available.

From April 2009 until March 2010 monitoring data of fluctuations in the groundwater table, and high temporal resolution data of groundwater quality, have been collected in ten groundwater observation wells. Three-dimensional geological and groundwater flow modeling of Hanko cape aquifer has been constructed from the geological and geophysical data, utilizing the integration of ArcGIS/ ArcInfo and Groundwater Modeling Software (GMS). Figure 3 shows a 3D view of a steady-state groundwater model of the Hanko aquifer (Quaternary sediments).

Adaptation to climate change is still a new issue in Hanko and only a few things have been done so far. In the BaltCICA-project 


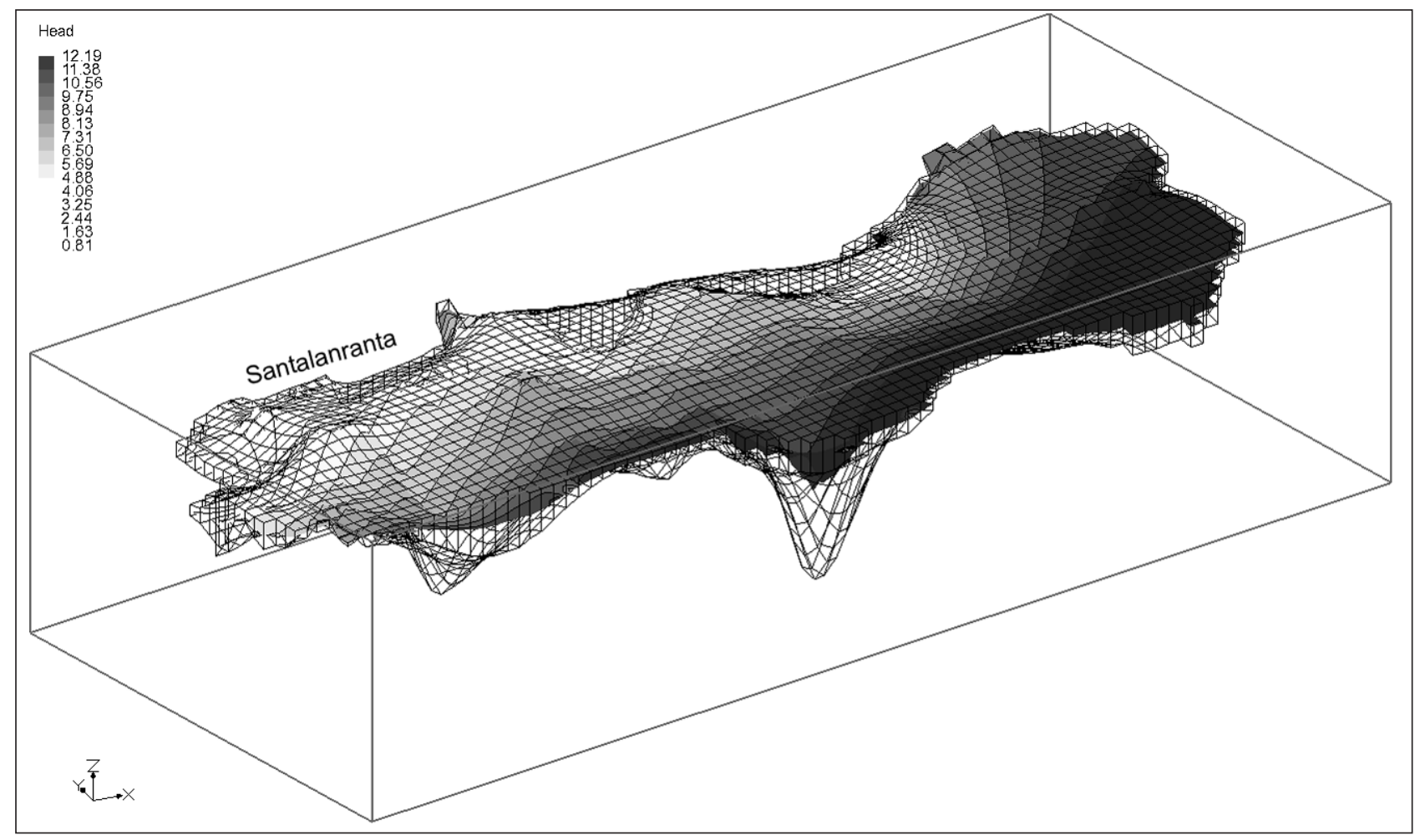

Figure 3. Steady-state groundwater model of the Hanko aquifer (S. Luoma).

Hanko has developed, together with the Geological Survey of Finland, a set of adaptation options that will be jointly assessed and compiled to safeguard future water supply.

The results can be utilized in similar geological formations in other regions of Baltic Sea. The adaptation options will be discussed in a workshop, and on an excursion, for water supply experts from the Baltic Sea Region.

\section{Klaipeda}

The Klaipeda is an important seaport of Lithuania, which faces several environmental problems that potentially could be affected by climate change, including coastal erosion, sea level rise, increasing geohazards, and possible decrease of groundwater resources.

All potable water resources $(100 \%)$ in Lithuania are extracted from groundwater aquifers. The amount of extracted groundwater resources is up to 2.2 million $\mathrm{m}^{3}$ per day, or 25.5 thousand litres per sec. Approximately a half of the evaluated groundwater resources is related to Quaternary deposits, including alluvial sands. The other half are located in the Cretaceous, Permian, and Devonian bedrock. The groundwater of the pre-Quaternary bedrock is artesian and generally of good quality. The chemical composition of some groundwater bodies is altered by natural saline water intrusions, which are in turn partly caused by groundwater abstraction. Despite generally good quantity and quality, the drinking water supply is facing serious problems in rural areas. According to investigations of the State Public Health Service under the Ministry of Health, and the Lithuanian Geological Survey, over $50 \%$ of the examined shallow groundwater dug wells for rural water supply in Lithuania do not meet requirements of the bacteriological quality, while $48 \%$ of them are polluted by nitrogen compounds (Satkunas et al., 2009).
Since 1962 a national groundwater monitoring program has been carried out in Lithuania (Groundwater..., 2008) and has shown that climate change is affecting shallow groundater bodies (Fig. 4). The increase in mean temperatures, together with lower precipitation amounts, and an increase in summer dry spells, were observed during the last 15 years, and has resulted in lower shallow groundwater levels. Therefore, this period is a time span of a general decrease of shallow groundwater resources, which in turn has most probably also led to a decrease in recharge rates of both deeper, and bedrock, aquifers.

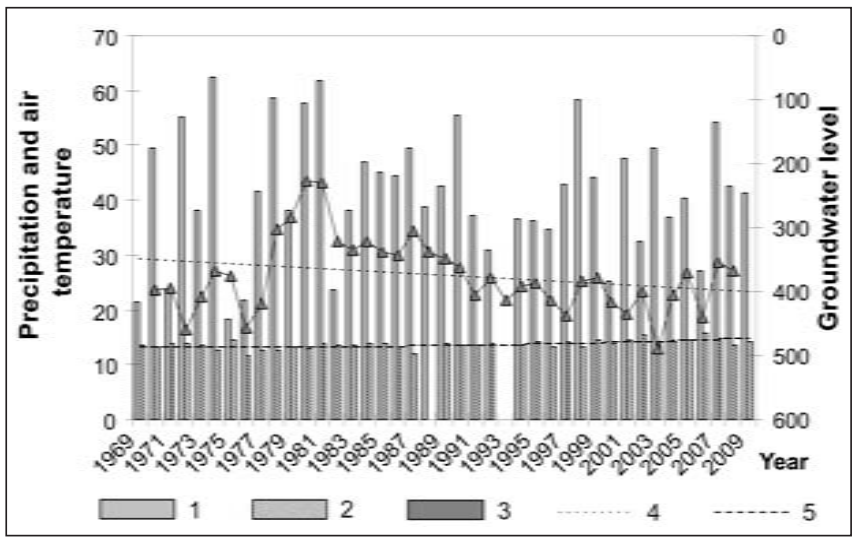

Figure 4. Shallow groundwater levels for the period 1962-2009 in Lithuania (as exemplified by the Mikuziai station) indicating: the last 15 years are the period of decreasing levels, particularly low levels were observed in 2003-2004 and 2006 (Giedraitiene, 2009). Legend: 1 - annual precipitation (cm); 2 - mean annual air temperature ${ }^{\circ} \mathrm{C} ; 3$ - depth of groundwater level below ground surface (cm); 4 - linear trend of shallow groundwater level; 5 linear trend of mean air temperature. 


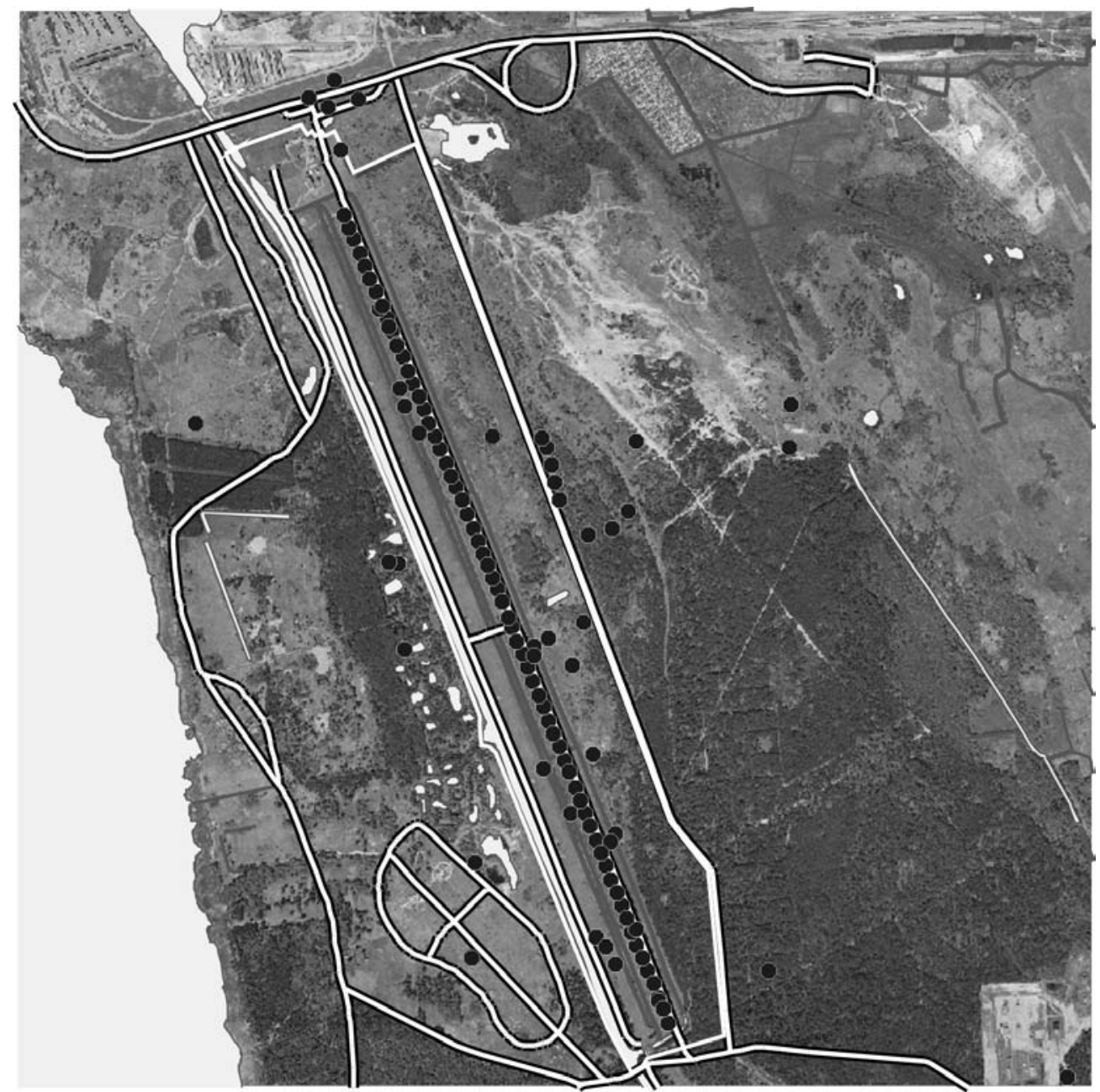

Figure 5. Location of wells in the $3^{\text {rd }}$ well field of Klaipeda. The groundwater resources of this well field are very closely related with the surface water bodies. geologists can support decisionmakers in analyzing climate change scenarios and the potential environmental and socio-economic impacts. Geology draws on a long history of climate (change) information and is able to carry out assessments based on experience and empirical data. One important question quickly arising in the cooperation with decision-makers is the one on the uncertainty of climate change scenarios. It is thus of great advantage for geologists to draw on experience and empirical data sets that can help to show potential speed and impact of climatic changes. Also, it is a fact that many current land-use concepts are not reasonably adapted to the current climate, including the potentially extreme events. In other words, climate change adaptation must start with adapting to the current climate, to understand the nature and effects of extreme events. It has in fact often proven plausible to make overlays of past climates and evolving land-use patterns, to identify potential future challenges, such as changes in flood prone areas. The communication with planners has shown that the multidisciplinary cooperation with geology is applicable in planning practices.
Groundwater for public water supply in the Klaipeda district is extracted from 4 different aquifers. Both the chemical and quantitative status of the aquifers is good.

The greatest groundwater extraction is from the $3^{\text {rd }}$ well field which is located on the banks of the Wilhelm channel (Fig. 5). It supplies drinking water for the southern part of Klaipeda and most of its resources $\left(\sim 70000 \mathrm{~m}^{3} / \mathrm{d}\right)$ are surface water. The groundwater resources in this well field are shallow and climate change impacts are quickly noticed.

The BaltiCICA project's Klaipeda case study is compiling hydrodynamical models for the Klaipeda district groundwater resources. An evaluation of potential climate change impacts is based on different climate change scenarios that shall support the definition of adaptation measures on both the use, and the protection, of water resources, including cost-benefit analyses.

\section{Conclusions}

The examples presented show that geology continues to be a modern and up-to-date branch of science that is well placed to answer important emerging societal questions. Even though future climate changes might not belong to the core tasks of geological research,

\section{Acknowledgements}

Authors express cordial thanks to Colin J. Simpson IUGS Councillor (2008-2012) for valuable remarks improving the paper and English review.

\section{References}

Adapting to climate change: Towards a European framework for action: white paper, 2009. Commission of the European Communities, Brussels, COM (2009) 147 final, $16 \mathrm{pp}$.

Finland's National Strategy for Adaptation to Climate Change, 2005. Ministry of Agriculture and Forestry of Finland, Publication 1a/2005, 280 pp.

Gerstengarbe, F.W., Werner, P.C., 2009. A short update on Koeppen climate shifts in Europe between 1901 and 2003: Climatic Change, v.92, no.1-2, pp. 99-107.

Giedraitiene, J., 2009. Shallow groundwater resources: Groundwater monitoring in Lithuania 2008: Bulletin, pp. 10 (CD) (in Lithuanian with English summary).

Graham, L.P., 2004. Climate Change Effects on River Flow to the Baltic Sea: Ambio, v.33, no.4-5, pp.235-241. 
Granberg, K., 2000. Kokkolan vanhasatamanlahden kehitys v. 2000-2200: Keski-Suomen Ympäristökeskus.

Groundwater Monitoring in Lithuania 2008. Bulletin, 2009: Lithuanian Geological Survey, Vilnius, 71 pp. (in Lithuanian with English summary). htpp://www.lgt.lt.

Haanpää, S., 2008. Climate change and spatial planning in the Baltic Sea region - reducing risks or raising vulnerabilities? Conference MEMO 8.2.2008, pp1-8.

htpp://www.astra-project.org/03_071210_espoo_astraconference_ final.html.

Hilpert, K., Mannke, F., Schmidt-Thomé, P., 2007. Towards climate change adaptation strategies in the Baltic Sea region: Geological Survey of Finland, Espoo, pp.1-55.

JHS 163 Suomen korkeusjärjestelmä N2000., 2008. JUHTA - Julkisen hallinnon tietohallinnon neuvottelukunta, pp. 1-16. http://docs. jhssuositukset.fi/jhs-suositukset/JHS163/JHS163.doc.

Knutson, T.R., McBride, J.L., Chan, J., Emanuel, K., Holland, G., Landsea, C., Isaac Held, Kossin, J.P., Srivastava, A.K., Sugi, M., 2010. Tropical cyclones and climate change: Nature Geoscience, no. 3, pp.157-163.

Meier, H.E.M., Broman, B., Kallio, H., Kjellström, E., 2006. Projections of future surface winds, sea levels, and wind waves in the late $21^{\text {st }}$ century and their application for impact studies of flood prone areas in the Baltic Sea region. In: Schmidt-Thomé, P. (ed.), Sea Level Changes Affecting the Spatial Development of the Baltic Sea Region: Geological Survey of Finland, Special Paper 41, pp.23-43.

Pielke, Jr. R. A., Gratz, J., Landsea, Ch. W., Collins, D., Saunders, M. A., Musulin, R., 2008. Normalized Hurricane Damages in the United States: 1900-2005: Natural Hazards Review, v.9, no.1, pp. 29-42.

Planning Sustainable Cities: Policy Directions: Global Report on Human Settlements 2009. Abridged Edition, 2009. United Nations Human Settlements Programme (UN-Habitat), 98 pp.

Ruosteenoja, K., Jylhä, K., Tuomenvirta, H., 2005. Climate scenarios for FINADAPT studies of climate change adaptation: Finnish Environmental Institute Mimeographs 345: FINADAPT Working Paper 15, pp.1-38.

Sadoff, C., Muller, M., 2009. Water Management, Water Security and Climate Change Adaptation: Early Impacts and Essential Responses: Global Water Partnership: TEC Background Papers No.14, August 2009.

Satkunas, J., Arustiene, J., Kanopiene, R., 2009. Environmental geology in Lithuania, state-of-art and European context: Special Report: Geopollution Science, Medical Geology and Urban Geology: Japanese Society of Geo-pollution Science, Medical Geology and Urban Geology, v.5, no.1/ 2, pp.25-33.

Schmidt-Thomé P., 2006. Integration of natural hazards, risks and climate change into spatial planning practices: Geological Survey of Finland, Espoo, pp.1-31

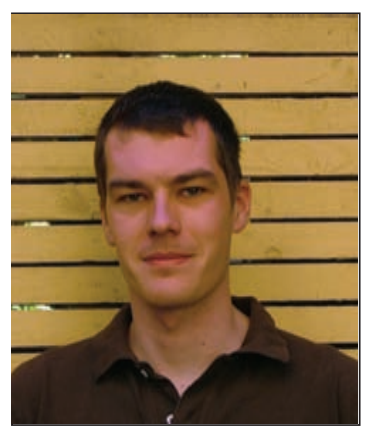

Johannes Klein has worked for the Geological Survey of Finland since 2004. He graduated from the University of Stuttgart in environmental engineering. His current research focus is on risk assessment, climate change adaptation and regional and urban development. He has participated in projects designated to science-stakeholder cooperation and regional development funded by the EU. He is the coordinator of the BaltCICA project.
Schmidt-Thomé, P., (ed.), 2006, Sea Level Changes Affecting the Spatial Development of the Baltic Sea Region: Geological Survey of Finland, Special Paper 41, Espoo, pp1-154.

von Storch, H., Weisse, R., 2008. Regional storm climate and related marine hazards in the Northeast Atlantic. In: Diaz, H.F. and Murnane, R.J. (eds.), Climate Extremes and Society, Cambridge: Cambridge University Press, pp. 54-73.

Topics Geo: natural catastrophes 2008. Analyses, assessments, positions, 2009: Munich Re, pp. 1-42.

Tarvainen, T., Jarva, J., Klein, J, Luoma, S., Backman, B., 2010. Geological and geochemical methods in environmental risk assessment in urban areas: Geological Survey of Finland, Special Paper, submitted.

Vestøl, O., 2006. Determination of Postglacial Land Uplift in Fennoscandia from Leveling, Tide-gauges and Continuous GPS Stations using Least Squares Collocation: Journal of Geodesy, v.80, no. 5, pp.248-258.

Water protection and management, 2008. Summaries of the EU legislation. http://europa.eu/scadplus/leg/en/s15005.htm.

Zektser I. S., 2000. Groundwater and the Environment: Application for the Global Community, USA: CRC Press, 192 pp.

Zektser, I.S. Everett, L.G., 2004. Groundwater Resources of the World and their Use: IHP-VI, Series on Groundwater no. 6. UNESCO, Paris, 346 pp.

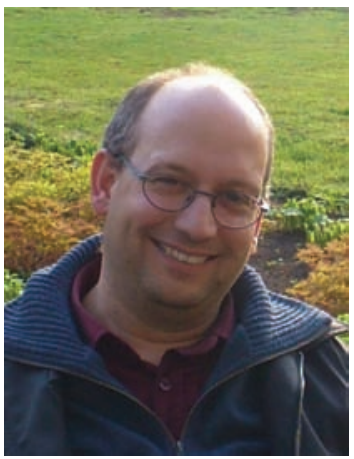

Philipp Schmidt-Thomé is a Geographer (Msc.) and holds a $\mathrm{PhD}$ in Geology. As a senior scientist at the Geological Survey of Finland he is specialized on natural hazards and climate change adaptation, focusing on interdisciplinary cooperation with spatial planning and regional development. He has worked as a project manager in European Regional Development Fund and research projects, as well as in special expert assignments for the EU Commission.

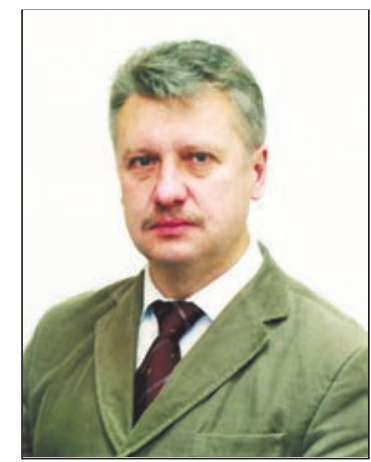

Jonas Satkunas is Deputy Director of the Geological Survey of Lithuania (since 1994), Field of responsibilities: planning and implementation national and international geoscientific research programmes. He is Associate Professor (since 2007) of Vilnius University. He was Co-director of the IUGS Geoindicators Initiative (in 20002006), Secretary General of IUGS Commission Geosciences for Environmental Management (GEM) (in 2004-2008). At present - member of the IUGS-GEM Working Group on Climate Change Adaptation and other professional bodies. 